\title{
Challenges and Opportunities in Strengthening ASEAN Space Technology Cooperation
}

\author{
Astri Rafikasari ${ }^{1}$ \\ Defence Diplomacy Department, Indonesian Defence University
}

Sutrimo Sumarlan

Defence Diplomacy Department, Indonesian Defence University

Yoedhi Swastanto

Defence Diplomacy Department, Indonesian Defence University

\author{
Keywords \\ International cooperation; \\ regional cooperation; space \\ cooperation, challenges; \\ opportunities
}

\begin{abstract}
ASEAN is regional cooperation between countries in the Southeast Asia region to benefit its member states. Amidst much ongoing teamwork, regional space cooperation has not been optimized as it is still limited to the use of technology. By applying a qualitative method, this paper aims to describe the challenges and opportunities in strengthening the ASEAN Space Technology Cooperation. It may either hinder or even potentially frame a sustainable international relation that accommodates ASEAN member states to develop more possibilities to maximize the use of space technology. This literary study argues that ASEAN Space Technology Cooperation may become a robust bridge to transfer space technology, strengthen national, regional, and international security, enhance economic growth, and means of transferring knowledge or space education to its member states.
\end{abstract}

\section{Introduction}

Changes in the global strategic environment have occurred so rapidly, which is marked by the development of increasingly sophisticated technology that has implications for changes in the international, regional, and national order. The flow of globalization can no longer be stopped to enter various countries in the world. Globalization is accompanied by increasingly sophisticated technological developments, where the world has entered the era of industrial revolution 4.0. The presence of the 4.0 industrial revolution was marked by the development of artificial intelligence, big data, robotic, internet of things (IoT), and the development of digital technology. Digital technology has taken over various roles in the life of the nation and state. Digital technology has spread rapidly in various corners of the world. Information and communication technology (ICT) has also historically been considered a significant driver of the global economy (Mubarak, 2018).

\footnotetext{
${ }^{1}$ Corresponding email \xastrijigannas@gmail.com
} 
Whether we realize it or not, currently, technology has a significant role. Digital technology is one of the developments in space technology. There is a saying that who controls technology will rule the world, who controls space technology will rule the world. It is a saying that describes the influence of technology, especially space technology, in daily human life. Digital information technology and the internet now seems to have ruled the world because it dramatically facilitates human activities, and many people who depend on internet networks/ digital technology. Through an internet connection, any information will efficiently and quickly spread throughout the world.

However, the development of space technology in various countries in the world is uneven. There is a gap in the development of extensive space technology between rich and developing countries, this also happens in the Association of Southeast Asian Nations (ASEAN) member states. In the fields of science and technology, cooperation related to space has also been carried out. Cooperation related to space is contained in the ASEAN Economic Community forum, namely the ASEAN Ministerial Meeting on Science and Technology (AMMST) in the Committee on Science and Technology (COST). However, the scope of the cooperation is still related to the use of space technology which is contained in the SubCommittee on Space Technology and Application (SCOSA), while space cooperation related to space technology development has not yet been carried out.

The principle to unite space activities in the ASEAN region to be more efficient is essential to do because the capabilities of ASEAN member states in space technology are different. In the development of space technology, we cannot do it alone. The hightech, high-money, and high-risk nature of space technology make a country have to cooperate with other countries. Concerning ASEAN, then how can this cooperation related to space technology be carried out. Opportunities and challenges in realizing space technology cooperation in the ASEAN framework must be identified to be able to formulate a more optimal space cooperation scheme. S. Rajaratnam, Deputy Prime Minister of Singapore, in August 1967, when ASEAN was formed, said that "We must think not only of our national interests but posit them against regional interests: that is a new way of thinking about our problems. We must make these painful and difficult adjustments. If we are not going to do that, then regionalism remains a utopia" (Abad, 1997).

From S. Rajaratnam's statement, the importance of cooperation, especially regional cooperation, is increasingly strengthened. Moreover, space cooperation in the ASEAN level related to special space technology becomes one of the collaborations that must be initiated immediately, further to strengthen ASEAN's role in space-related to international world. However, at present, the ASEAN space technology cooperation is still not optimal in its implementation and the object of cooperation, some many opportunities and challenges must be faced in strengthening space technology cooperation between ASEAN member states. The purpose of this paper is to identify opportunities and challenges in strengthening ASEAN space technology cooperation and formulate a more optimal cooperation scheme that can be carried out within the framework of ASEAN space technology cooperation.

\section{Conceptual Framework}

In order to ground our study, we employ three conceptual frameworks, namely international cooperation, regionalism, and space diplomacy. As seen below, those three are deeply engaged in helping us understand and identify the challenges and opportunities of possible space technology cooperation in and within ASEAN member states. 


\section{International Cooperation}

International cooperation is part of the study of international relations. According to Holsti, cooperation can be defined as follows (Holsti, 1997, pp. 652-653):

1. The view that two or more interests, values, or goals meet one another and can produce something, be promoted, or be fulfilled by all parties at once;

2. The view or hope of one country that the policies decided by other countries will help the country to achieve its interests and values;

3. Certain agreements or problems between two or more countries in order to take advantage of equality of interest or conflict of interest;

4. Official or informal rules regarding future transactions made to carry out the agreement;

5. Transactions between countries to fulfill their agreement.

Therefore international cooperation can be defined as relations/interactions between countries carried out by state actors and nonstate actors to achieve specific goals. International cooperation can be divided into three forms, namely (Holsti, 1997, pp. 652-653):

1. bilateral cooperation, is a form of international cooperation between one country with another country, or with other non-state actors (occurs between 2 state actors or non-state actors);

2. multilateral cooperation is a form of international cooperation between one country with many other countries, or with many other non-state actors (occurring between more than two state actors or non-state actors);

3. regional cooperation is a form of cooperation carried out by state actors or non-state actors who are in the same region.

While the motive for conducting cooperation is related to space technology cooperation, it can be linked to science \& technology (S\&T) cooperation. The motivating factors and motives of countries to engage in international cooperation vary greatly. Flanagan, K. et al. (2012) have identified two broad sets of goals for international S\&T cooperation. First, the fundamental objectives, which directly lead to proof of S\&T, such as collaboration among researchers or building large-scale infrastructure. Second, the external objectives that focus on supporting other policies such as foreign policy, economic/ market policy, or development policy.

In their study entitled "Basic Principles for Effective International Science, Technology and Innovation Agreements: Main Report" (2014, pp. 9-12) Fikkers and Horvat identified 15 motives in conducting international S\&T cooperation on a spectrum that ranged from 'narrow' agreements to 'broad' agreements, namely: 1) Increase cooperation; 2) Exchange of experience; 3) Achieve changes in R\&D funding patterns; 4) Increase the economies of scale of $R \& D$; 5) Increase access to research infrastructure; 6) Increase human capital; 7) Improve the reputation of state research; 8) Increase innovation and market orientation; 9) Develop a general strategy; 10) Achieve research excellence; 11) S\&T capacity development; 12) Highlight cooperation during diplomatic visits; 13) Protect security; 14) Change diplomatic relations; and 15) Promote public diplomacy. As seen on those lists, we could see that there are, in fact, different kinds of aspects in which each of it is important in conducting space technology cooperation, which may intimately be engaged in regionalism.

\section{Regionalism}

ASEAN is very identical to the concept of regionalism. Regionalism can be interpreted as relations between countries or interest groups that are well institutionalized in an area to achieve specific goals (Anwar, 1996). What is meant by these specific objectives is promoting the integration of the region wherein the implementation oftentimes the state plays a 
dominant role and is realized through certain organizations and engages in specific fields (Santos, 2008). The definition indicates that aspects of regional cooperation are comprehensive covering various fields, namely economic, social, political, and defense and security. So the concept of multilateralism cooperation arranged in a regional organization is very crucial to integrate and enhance cooperation between countries in a region (Weiss, 2010), for example, is cooperation within the ASEAN framework. The concept of regionalism in this study will explain the importance of space technology cooperation between ASEAN member states.

\section{Space Diplomacy}

Diplomacy in traditional terms is defined as the dialogue between countries (Schrogl, 2016). Whereas the term space diplomacy by the space community is defined as (Haro et al., 2016):

1. Ideas for formulating and implementing practical initiatives so that the interests of countries meet with each other in space.

2. The art of negotiation to coexist peacefully in space for the future of humanity.

Space Diplomacy can be interpreted as dialogue, negotiation in international cooperation, which is motivated by interests related to space. At present, many international collaborations are motivated by the importance of developing joint space technology, because the nature of space technology is high tech, high risk, and high money. Science \& Technology has now played an important role in creating a globally connected modern society. In international affairs, diplomacy, technology, and economics are the most essential tools for any country. Historically, science and technology (S\&T) have been one of the main currencies for exchange and dialogue between human society and sovereign states. In this modern era, it emerged as an essential instrument of techno-economic forces that will shape the changing dynamics of international relations and global affairs. Diplomacy is the main instrument of dialogue between countries. It is the art of negotiating to protect one's interests and promote one's influence in international affairs. For each sovereign country, both technology and diplomacy are essential tools for managing international relations, which in essence protect national security and project national power (Mallik, 2016, p. 7).

S\&T plays a crucial role in building the dynamics of the balance of power between sovereign states. It offers alternative channels of engagement among countries that may have political differences so that it plays an essential role by influencing the dynamics of the balance of power between sovereign states. Advances in S\&T often rely on international flows of people and ideas, and this is happening now more than ever. Overcoming the cold war, exchanges between scientific organizations and universities are essential channels for informal discussions on nuclear issues and other sensitive technologies. Different aspects of the role of science, technology and policy innovation, diplomacy, and international relations can be seen in three different dimensions of scientific diplomacy, namely (The Royal Society, 2010):

1. Science in Diplomacy - strengthening the contribution of science to foreign policy objectives.

2. Science for Diplomacy - uses S\&T cooperation to improve relations between countries.

3. Diplomacy for Science (Diplomacy for Science) - facilitating international science collaboration.

\section{Methods}

This paper uses descriptive qualitative research methods. Qualitative research is one form of research that describes and analyzes human social reality (Pusbindiklat LIPI, 2017, p. 47). Meanwhile, descriptive research is research 
aimed at describing and describing and mapping facts based on a particular perspective or frame of mind (Mahmud, 2011, p. 100). Data collection techniques are done through library research. A literature study is a data collection technique by conducting study studies of books, literature, notes, and reports that have to do with the problem being solved (Nazir, 2003, p. 27).

\section{Results and Discussion}

\section{ASEAN Science and Technology Development}

ASEAN has played a central role in maintaining peace and security in the region for the past 50 years. As a platform for regional cooperation, ASEAN is one of the most successful examples in the world. ASEAN has become a significant channel for governments in Southeast Asia to overcome joint challenges and manage disputes among member states jointly. ASEAN has been described as a fulcrum where the Asia Pacific security, the political and economic architecture will be built. ASEAN has also become a channel for small and medium-sized countries in the region to enhance their negotiating positions with the world's major powers (Parks, et al., 2018).

Until now, ASEAN's role in development has primarily been focused on (Parks et al., 2018, p. 4):

1. Economic integration - The ASEAN Secretariat and the ASEAN Economic Community (ASEC) have led a series of policy alignment and capacity development programs since 2002 to promote economic integration. Many dialogue partners have coordinated some of their regional and bilateral assistance to support this ASEAN-led initiative. The Initiative for ASEAN Integration (IAI) has also played a significant role in narrowing the development gap between the more developed and least developed ASEAN member states.
2. Cross-border challenges - the ASEAN Secretariat and relevant sectoral bodies have led many programs to address cross-border problems, including human trafficking, safe migration, infectious diseases, and cross-border haze, among others.

3. Building capacity - ASEAN sectoral bodies have used development cooperation for a wide range of capacity building programs, most of which focus on relevant government officials, includes regional workshops, consultations, and training, usually to support sectoral agency work plans and joint agendas.

The Bangkok Declaration which established the basis for the formation of ASEAN on 8 August 1967 recognized the urgency for the five-member states (i.e., Indonesia, Malaysia, the Philippines, Singapore, and Thailand) to engage in joint efforts to accelerate economic growth, social progress and cultural development in the region. Recognizing further that S\&T is a necessary and indispensable tool for achieving this goal, an Ad hoc Committee for S\&T was established. The first meeting was held in Jakarta, Indonesia, on April 27-29, 1970, to discuss ways to promote and intensify cooperation in S\&T. Explicitly, the meeting agreed that ASEAN cooperation in S\&T must be guided by the following objectives (ASEAN Secretariat, 2017b):

a. To initiate and intensify regional cooperation in scientific and technological activities;

b. To produce and promote the development of scientific and technological expertise and personnel in the ASEAN region;

c. To facilitate and accelerate the transfer of scientific and technological developments between ASEAN member states and from developed industrial countries to the ASEAN region; 
d. To provide support and assistance in the application of research and development results, and in the more effective use of natural resources in the ASEAN region; and

e. To provide support for the implementation of current and future ASEAN programs.

Therefore ASEAN has compiled the ASEAN Plan of Action on Science, Technology, and Innovation (APASTI) 2016-2025. The vision of APASTI is "ASEAN, which supports Science, Technology, and Innovation, which is innovative, competitive, vibrant, sustainable and economically integrated." The objectives of APASTI 2016-2025 are (ASEAN Secretariat, 2017a):

1. ASEAN Science, Technology and Innovation addresses the significant challenges of the new millennium;

2. ASEAN which is economically integrated which involves active collaboration between the public \& private sectors, especially SMEs and enhanced talent mobility;

3. A deep awareness of S\&T, and the impact of the benefits of S\&T at the bottom of the pyramid;

4. An economy is driven by innovation with in-depth Science, Technology enculturation and a seeding system and S\&T sustainability by utilizing Information and Computer Technology (ICT), and resources from the talented young, female and private sectors;

5. Active R\&D collaboration, technology commercialization, and entrepreneurship and a network of centers of excellence; and

6. Enhanced science, Technology management system in the new Atomic Energy Commission (AEC) so that it can support ASEAN innovation in reaching global markets and which promote innovation, integration, and narrowing of development gaps in all ASEAN member states.

The following are strategies to achieve APASTI 2016-2025, namely (ASEAN Secretariat, 2017a):

1. Strengthen strategic collaboration between academics, research institutions, networks of centers of excellence, and the private sector to create useful ecosystems for capacity building, technology transfer, and commercialization. Done by:

a. Intensifying the involvement of academics, the private sector, and related partners in the planning, implementation, and assessment of joint ventures in human resource development, as well as research and development;

b. Improve and maintain the use of the ASEAN Science and Technology Network (ASTNET) and strengthen other S\&T networks to facilitate information exchange;

c. Establish a policy framework including IPR protection, risk, and benefit-sharing mechanisms for collaboration and technology transfer between centers of excellence; and

d. Strengthen regional STI initiatives in priority areas, including the Sustainable Development Goals.

2. Increase the mobility of scientists and researchers, connectivity between communities, and strengthen the involvement of women and youth in the integrated management system (IMS). Done by:

a. Establish a policy framework for the exchange of scientists, researchers, and students including women and youth;

b. Establish scholarship programs, scholarships and or attachments for students, researchers and other STI personnel;

c. Intensifying efforts towards standardizing certification and 
accreditation in education and technical competence; and

d. Expand opportunities for women, youth, and disadvantaged groups to contribute to STI through incentives and support mechanisms.

3. Building innovative systems and smart partnerships with dialogue and other partners to maintain IMS companies to support Micro, Small, and Medium Enterprises (MSMEs), maintain knowledge creation and IMS applications to enhance competitiveness. Done by:

a. Building support mechanisms such as guidance and incentive programs to support and maintain IMS companies from the beginning to the next competitive level of development; and

b. Involve dialogue and other strategic partners in joint ventures regarding STI initiatives that are feasible and commercially viable.

4. Increase public awareness and strengthen the IMS enculturation to enhance ASEAN scientific and technological cooperation. Done by:

a. Encouraging the participation of scientists, researchers, and industry in ASEAN S\&T events such as the ASEAN Food Conference (AFC) and the ASEAN Science, Technology and Innovation Week (ASTIW);

b. Improve the content of articles published in the ASEAN Science and Technology Journal for Development and other journals;

c. Utilizing ASTNET in publicizing ASEAN initiatives on IMS;

d. Developing databases and resource networks to facilitate the exchange of information and technical cooperation between institutions in the public and private sectors, and;

e. Involve relevant stakeholders in developing and implementing an effective STI communication and enculturation plan.
The cooperation related to space is accommodated in the ASEAN Committee on Science and Technology (COST), more specifically in the Space Technology and Application Sub-Committee (Sub-Committee on Space Technology and Application - SCOSA). Activities that have been carried out relating to space include (ASEAN Secretariat, 2017a):

Table 1. SCOSA Activities in 2007, 2010, and

\begin{tabular}{|c|c|c|}
\hline 2007 & 2010 & 2015 \\
\hline $\begin{array}{l}\text { 1. Spatial Data } \\
\text { Infrastructure Project } \\
\text { 2. ASEAN-Pakistan } \\
\text { Geoinformatics } \\
\text { Workshop } \\
\text { 3. Training Workshop on } \\
\text { Application of Satellite } \\
\text { Altimetry Data }\end{array}$ & $\begin{array}{l}\text { 1. ASEAN-Japan Cooperation on } \\
\text { Application of Crop Growth } \\
\text { Simulation Model with } \\
\text { Satellite Remote Sensing and } \\
\text { Geographic information } \\
\text { System Techniques for } \\
\text { Agricultural Crop Potential } \\
\text { Vield Monitoring and } \\
\text { Estimating } \\
\text { 2. ASEAN-Japan Utilization of } \\
\text { Satellite Images on Disaster } \\
\text { Management Project }\end{array}$ & $\begin{array}{l}\text { 1. ASEAN-Russia Workshop on } \\
\text { the Practical Application of } \\
\text { the Earth Remote Sensing } \\
\text { Technologies to Solve Social } \\
\text { and Economic Challenges } \\
\text { 2. ASEAN-Russia Seminar on } \\
\text { the Common Use of the } \\
\text { GLONASS/GPS Satellite } \\
\text { Navigation Technologies }\end{array}$ \\
\hline
\end{tabular}

(Source: ASEAN Secretariat, 2017a, pp. 20-27)

While the ongoing project is a joint project between SCOSA and the SubCommittee on S\&T Infrastructure and Resources Development (SCIRD) in the "ChinaASEAN Science and Technology Partnership Program (China-ASEAN STEP Program)":

1. China-ASEAN Technology Transfer Center (CATTC);

2. Talented Young Scientist Visiting Program;

3. Joint Laboratory Program; and

4. Remote Sensing Satellite Data Sharing and Service Platform.

Whereas the goals and priorities of the 2016-2025 SCOSA activities are as follows: 
Table 2. SCOSA Activities 2016-2025

\begin{tabular}{|c|c|}
\hline Objectives & Priority Areas \\
\hline $\begin{array}{l}\text { 1. Serve as platform to formulate and coordinate } \\
\text { collaborative and cooperative programmes and } \\
\text { projects on space science and technology, in such } \\
\text { areas as, remote sensing, satellite meteorology, } \\
\text { space education and research, communication, } \\
\text { environmental and natural resource management, } \\
\text { and development planning; } \\
\text { 2. Review the status and capability on space } \\
\text { technology in the region and promote this } \\
\text { technology for natural resource and environment } \\
\text { management and sustainable development; } \\
\text { 3. Recommend mechanisms to involve government } \\
\text { agencies, industries and academe in promoting and } \\
\text { sustaining regional cooperation in space } \\
\text { technology, applications, education, research and } \\
\text { development; } \\
\text { 4. Exchange and sharing of information, best practices } \\
\text { and expertise on national policies, programmes and } \\
\text { planning in all areas of space technology and its } \\
\text { applications among ASEAN member states; } \\
\text { 5. Facilitate and accelerate the transfer of space } \\
\text { technology and its applications to the ASEAN } \\
\text { region; } \\
\text { 6. Promote and facilitate collaborative and cooperative } \\
\text { activities on space technology and its applications } \\
\text { with relevant international organisations; } \\
\text { 7. Advise COST on matters relating to space } \\
\text { technology and its applications; and } \\
\text { 8. Assist in securing financial support and funding } \\
\text { sources for ASEAN activities and projects relating to } \\
\text { space technology and its applications. }\end{array}$ & $\begin{array}{l}\text { 1. Geoinformatics: } \\
\text { Sensing (RS), Globate } \\
\text { Navigation Satellite System } \\
\text { (GNSS), Geographic } \\
\text { Information System (GIS); } \\
\text { 2. Spacerectechnology } \\
\text { applications, including space- } \\
\text { based communication, } \\
\text { Disaster Risk Reduction (DRR), } \\
\text { agriculture, environment and } \\
\text { resource monitoring, } \\
\text { Surveying and Mapping (SM), } \\
\text { and space astronomy and } \\
\text { space exploration; and } \\
\text { 3. Satellites, such as nano, micro } \\
\text { and small satellites, payloads } \\
\text { such as sensors, and ground } \\
\text { facilities. }\end{array}$ \\
\hline $\begin{array}{l}\text { To achieve the above objective, the SCOSA shall end } \\
\text { 1. Promote collaborative STA activities with relevant in } \\
\text { 2. Advise COST on any matters relating to STA ac } \\
\text { applications, education, research and development; } \\
\text { 3. Seek funding from within and outside ASEAN for the } \\
\text { 4. Promote STA capacity building in ASEAN region; } \\
\text { 5. Recommend STA projects promoting regional coope } \\
\text { 6. Promote the transfer of technology from more advar }\end{array}$ & $\begin{array}{l}\text { leavour to: } \\
\text { ernational organisations; } \\
\text { tivities especially regarding future } \\
\text { SCOSA activities; } \\
\text { ration; and } \\
\text { nced countries to ASEAN region. }\end{array}$ \\
\hline
\end{tabular}

(Source: ASEAN Secretariat, 2017a, pp. 44-49)

It can be seen the activities that have been carried out related to space cooperation, which is accommodated in SCOSA. So it can be seen that most of the activities that have been and will be carried out are more related to the application of space technology, especially satellite technology and remote sensing, as well as cooperation between ASEAN member states and other countries outside ASEAN. Meanwhile, technology related to technology transfer in the construction of satellite, rocketry and aviation constellations seems not to have been initiated in this ASEAN space collaboration. So that in the future, cooperation related to the development of space technology can be one of the agendas that must be carried out.

\section{The Space Technology Capabilities of ASEAN Member States}

The space technology capabilities of ASEAN member states will be elaborated through the following indicators, namely: 1) National Space Agency/ Institutions related to Space Activities; 2) UN Treaties on Outer Space; 3) Member of
United Nations Committee on the Peaceful Uses of Outer Space (UNCOPOUS); 4) Member of Asia-Pacific Regional Space Agency Forum (APRSAF); 5) Member of Asia-Pacific Space Cooperation Organization (APSCO); 6) National Space Policy/ Space Law; 7) Satellite Capability; 8) Remote Sensing Technology Capability; 9) Science \& Atmosphere Capability; 10) Aeronautics Capability; and 11) Rocket Technology Capability.

Table 3. The Technology Capabilities of ASEAN Member States

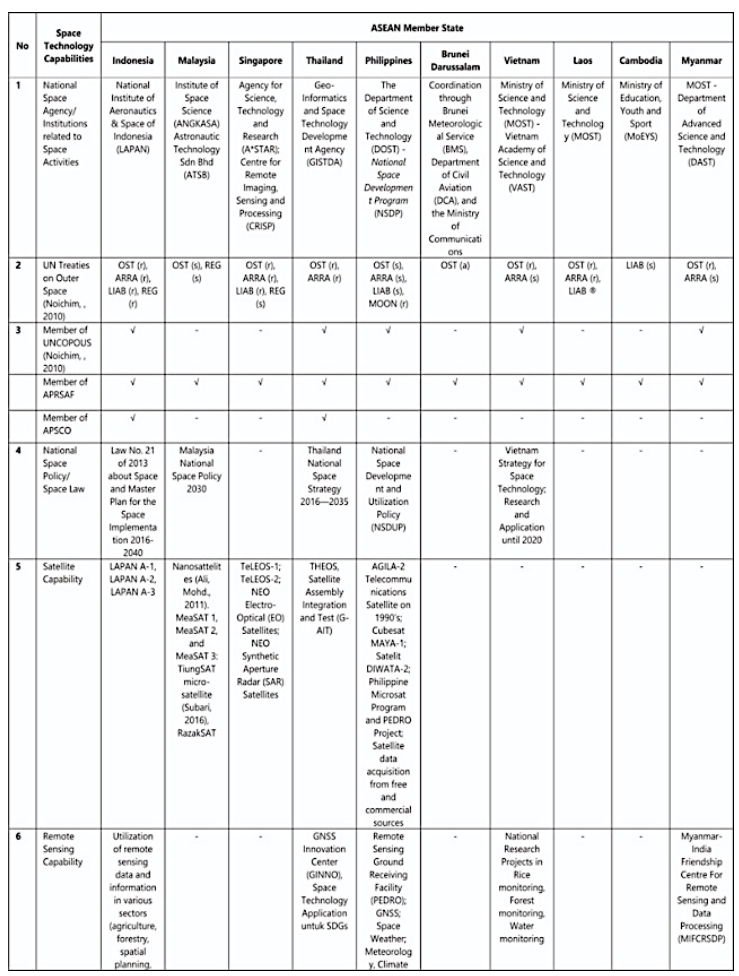




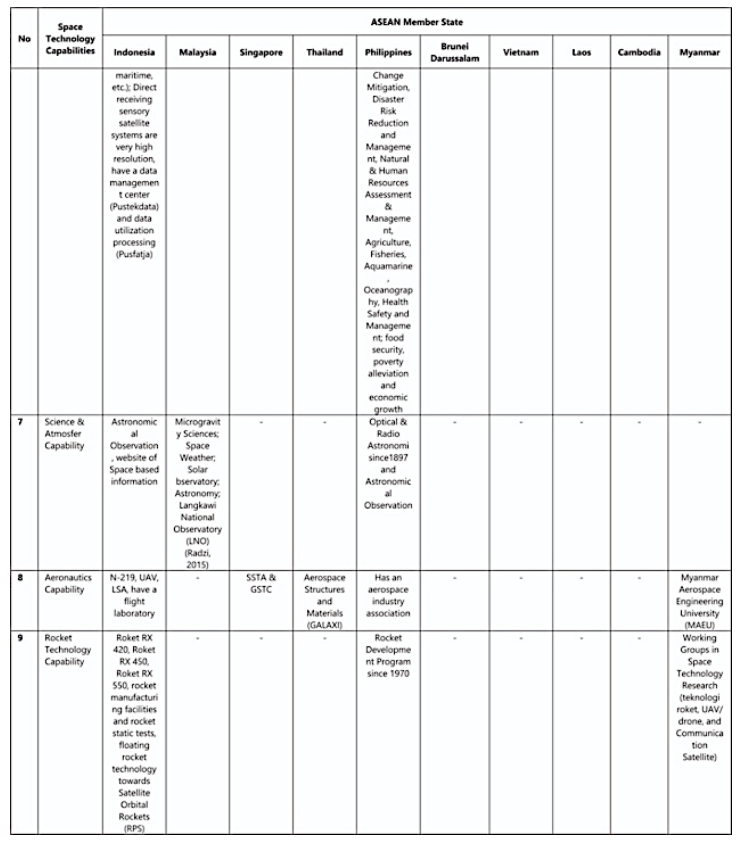

(Source: (LAPAN, 2019); (Noichim, 2010); (Radzi, 2015); (Sese, 2015); \& (Subari, 2016); and based on author analysis)

The space technology capabilities of ASEAN member states in table 3, which are described based on these indicators, illustrate that the development of ASEAN space technology has not yet been balanced. There are still gaps in technology development among ASEAN member states. The ability of space technology in ASEAN is still dominated by the pioneering countries of the establishment of ASEAN. Indonesia, Thailand, Malaysia, Singapore, and the Philippines are still the main ASEAN member states with the most capable space technology capabilities in the ASEAN region. However, variations in technological development between these countries also differ. Some developed flight technology, satellites, and rockets together. There are also those who only focus on developing satellite technology and remote sensing, and there are those who only focus on the development of the space industry.

This condition must also be considered as a basis for compiling so that it must be an essential concern in developing future space technology cooperation schemes. The involvement of countries in space organizations outside ASEAN must also be a matter of concern. ASEAN space technology cooperation can be a deterrence effect for other countries and space organizations. A stronger ASEAN space technology cooperation will make ASEAN not always dependent on other countries in developing space technology, not only be consumers of space technology but can play a role in the space industry as well.

\section{Challenges and Opportunities Strengthening ASEAN Space Technology Cooperation}

Space activities within the ASEAN framework have been included in the Sub-Committee on Space Application (SCOSA) as a sub-committee related to the use of space technology. Nevertheless, in the implementation of coordination between ASEAN member states in each SCOSA activity is still not running optimally. Space cooperation is still partial among ASEAN member states. The cooperation was also limited to the application of cooperation on space technology development. Associated with the development of space technology in terms of developing satellite launchers and satellite technology to be developed together has not been programmed. Therefore, related to the optimization of ASEAN space cooperation will be explained about the opportunities and challenges that must be faced to realize the ASEAN Space Cooperation as a container for the integration of space technology development in ASEAN that supports the ASEAN community integration. 
Table 4. Challenges and Opportunities of

\section{ASEAN Space Technology Cooperation}

\begin{tabular}{|c|c|c|}
\hline No & Opportunities & Challenges \\
\hline 1 & $\begin{array}{l}\text { Realizing the ASEAN Integration, the } \\
\text { ASEAN Community, ASEAN Connectivity, } \\
\text { supports the integration in R\&D related to } \\
\text { space technology }\end{array}$ & $\begin{array}{l}\text { Gaps between ASEAN member states } \\
\text { (both gaps in economic terms (income), } \\
\text { Human Resources (HR), Government } \\
\text { Structure, Infrastructure, and of course } \\
\text { the gap in the development of space } \\
\text { technology between ASEAN member } \\
\text { states, where there are no countries that } \\
\text { excel in special technologies such as } \\
\text { satellite technology and satellite launch } \\
\text { rockets, as well as differences in Space } \\
\text { technology specialization and } \\
\text { diversification between ASEAN member } \\
\text { states so that the space capabilities of } \\
\text { each country should be mapped. }\end{array}$ \\
\hline 2 & $\begin{array}{l}\text { The existence of the Industrial Revolution } 4.0 \text { as } \\
\text { a trigger for ASEAN member states to develop } \\
\text { their space technology }\end{array}$ & $\begin{array}{l}\text { Each country has different interests in } \\
\text { the development of space technology } \\
\text { (the importance of consensus in making } \\
\text { a roadmap for the development of } \\
\text { ASEAN space technology) }\end{array}$ \\
\hline 3 & $\begin{array}{l}\text { Some ASEAN member states have limited R\&D } \\
\text { facilities, expert scientists or national funds to } \\
\text { enable them to fully participate in space R\&D } \\
\text { activities, so ASEAN space cooperation will be } \\
\text { an opportunity for countries to get a share of } \\
\text { knowledge and transfer of related technology }\end{array}$ & $\begin{array}{l}\text { ASEAN member states in terms of space } \\
\text { technology there are no superior } \\
\text { countries, most countries are still in the } \\
\text { developing countries related to space } \\
\text { technology, so they are still dependent } \\
\text { on cooperation with other countries that } \\
\text { excel in developing space technology } \\
\text { (such as Japan, China, the European } \\
\text { Union) }\end{array}$ \\
\hline 4 & $\begin{array}{l}\text { The ASEAN region is strategic in developing } \\
\text { space technology (most ASEAN member } \\
\text { states are in the Equator region), suitable } \\
\text { for the development of rocket technology, } \\
\text { spaceport, and satellite development }\end{array}$ & $\begin{array}{l}\text { The funding mechanism for cooperation } \\
\text { (Cost Sharing Scheme) is unclear and } \\
\text { there are economic gaps between } \\
\text { ASEAN member states, and the clarity of } \\
\text { the Ownership of Property in } \\
\text { cooperation must also be determined. } \\
\text { Absence of a possible "solidarity fund" } \\
\text { to facilitate a redistributive mechanism } \\
\text { among members } \rightarrow \text { There is no } \\
\text { possibility of a "solidarity fund" to } \\
\text { facilitate redistributive mechanisms }\end{array}$ \\
\hline 5 & $\begin{array}{l}\text { Can encourage space researchers who } \\
\text { initially went to school and worked in other } \\
\text { countries who did not return to Indonesia } \\
\text { or their countries to become interested } \\
\text { again in applying their knowledge through } \\
\text { ASEAN Space Technology Cooperation. } \\
\text { And encourage the development of } \\
\text { aerospace-based education in ASEAN } \\
\text { member states }\end{array}$ & $\begin{array}{l}\text { Competition versus cooperation is still a } \\
\text { dilemma between ASEAN member } \\
\text { states, such as Indonesia and Malaysia } \\
\text { (there is still sentiment between } \\
\text { countries). There is related to the } \\
\text { geopolitical stability and regional } \\
\text { relation issues }\end{array}$ \\
\hline 6 & $\begin{array}{l}\text { Supporting the achievement of SDGs in the } \\
\text { ASEAN region, Space technology as a driver } \\
\text { to achieve ASEAN's SDGs }\end{array}$ & $\begin{array}{l}\text { Partial offers of cooperation from other } \\
\text { countries to ASEAN member states } \\
\text { (offers of bilateral cooperation) thereby } \\
\text { reducing the focus of ASEAN regional } \\
\text { space cooperation. }\end{array}$ \\
\hline 7 & $\begin{array}{l}\text { Support the integration of ASEAN Space } \\
\text { Generation so that they can actively } \\
\text { participate and contribute to international } \\
\text { space organizations (eg. Space Generation } \\
\text { Advisory Council (SGAC)) }\end{array}$ & $\begin{array}{l}\text { Determine who the coordinating } \\
\text { country in this ASEAN Space Technology } \\
\text { Cooperation }\end{array}$ \\
\hline 8 & $\begin{array}{l}\text { Having strong Macroeconomic } \\
\text { Fundamentals (specifically } 6 \text { ASEAN } \\
\text { member states) (Verbiest, 2011) }\end{array}$ & $\begin{array}{l}\text { There are no ASEAN member states } \\
\text { that are members of Missile } \\
\text { Technology Control } \\
\text { Regime (MTCR) (Sarma, 2019), so that it } \\
\text { will be difficult when there is a dual-use } \\
\text { technology transfer }\end{array}$ \\
\hline 9 & $\begin{array}{l}\text { Has a wealth of natural resources that are } \\
\text { large (oil, gas, coal, hydropower, mining, } \\
\text { agriculture, forestry) and biodiversity and } \\
\text { space technology can be used to manage } \\
\text { the existence of the diversity of natural } \\
\text { resources; and }\end{array}$ & $\begin{array}{l}\text { Building the competence of the ASEAN } \\
\text { young generation by increasing space } \\
\text { and aerospace technology-based } \\
\text { education. }\end{array}$ \\
\hline 10 & $\begin{array}{l}\text { ASEAN is the Most Successful Regional } \\
\text { Cooperation Experience outside the } \\
\text { European Union (Verbiest, 2011). It is } \\
\text { hoped that ASEAN space cooperation will } \\
\text { strengthen ASEAN's role in the } \\
\text { international world (detterence effect) }\end{array}$ & \\
\hline
\end{tabular}

(Source: (Verbiest, 2011); (Sarma, 2019); \& based on author analysis)
In the development of the international community, regional cooperation plays an important role. Regional cooperation can be defined as cooperation between countries in a particular region or a group of countries with the same political identity by establishing international organizations to serve the interests of member states such as economics, culture, and technology. The collaboration for the development of sustainable space among developing countries must be identified, and the benefits shared among the countries. In particular, there must be regional cooperation in geographically close countries, such as members of the ASEAN.

The benefits of such cooperation in exploration and use of space are numerous, including reducing the consumption of natural resources, increasing the distribution of work, the development and development of coordinated space knowledge and reducing competition among participating countries. Apart from various levels of economic, scientific, technological, and industrial development, there is regional space cooperation between ASEAN member states. This collaboration can be an effective way to stimulate the use of space technology applications and the development of space science and technology, and help bridge gaps in space science and technology knowledge among member states. This progress can also contribute to accelerating economic, cultural, and social growth and help developing countries skip the stages of development (Noichim, 2008, pp. 33-37).

International cooperation in space technology is beneficial for several countries to achieve common space science goals in the following fields (Mukherjee, 2018):

1. A more vigorous ASEAN space research program that leads to the development of special technological capabilities (development of satellites and satellite launch rockets, and spaceport) that enable the sharing of knowledge and technology transfer; 
2. Use of shared space infrastructure and space-based data sharing for resource management and social benefits.

3. National security agreement on space security among ASEAN member states.

4. Increased research in science, technology, engineering with a more significant number of ASEAN students/professionals, and their impact on education and the economy.

5. A better understanding of planetary science and technology for information and evaluation of the universe (impact on Astro-Physics).

\section{Optimization of ASEAN Space Technology Cooperation}

Based on the challenges and opportunities outlined above, the strategy to maximize ASEAN space technology cooperation can be carried out in the following ways, namely:

1. Identifying the Great Vision and Mission of ASEAN Space Technology Cooperation;

2. Identifying the capabilities of each ASEAN member country in terms of space technology and application of the space technology, as well as mapping the space industry in each country, so that it can map the contribution of each country;

3. ASEAN must have "One Space Dream", like having an ASEAN satellite or having an ASEAN satellite launch area (spaceport) such as the European Space Agency (ESA);

4. Identifying appropriate activity financing patterns for the integration of ASEAN space R\&D;

5. Identifying the patterns/forms of cooperation and what programs will be cooperated related to the development of space technology in the framework of one ASEAN;
6. Mapping the objects to have cooperated (space segment and ground segment);

7. Mapping experts/space experts in each ASEAN country;

8. Creating an ASEAN Space Cooperation Roadmap (Short-term, Medium-term and Long-term)

9. ASEAN member states need to increase their commitment and efforts to internalize ASEAN space programs and cooperation (adjusting national programs for each country into ASEAN space programs);

10. An effective coordination mechanism needs to be established (the structure of the ASEAN space cooperation organization must be established);

11. The ASEAN space cooperation program must involve other sectors outside the state sector (triple helix coordination), namely the government, private sector, and universities.

12. Based on the defense aspect, the ASEAN Space Technology Cooperation can also be used as a driver to develop the use of space technology for defense in the ASEAN region. The need to bring the issue of space technology cooperation in the ASEAN Defence Ministers Meeting (ADMM) forum.

\section{Conclusion}

The concept of ASEAN Space Technology Cooperation is an embodiment of the concept of Space for Diplomacy, where space is used as a media to build and strengthen relations between ASEAN member states. In optimizing ASEAN Space Technology Cooperation, challenges, and opportunities, both internal and external of ASEAN, emerge. In general, the challenges faced in strengthening ASEAN Space Technology Cooperation, are due to gaps in space technology development among ASEAN member states, where there are no countries that excel in special technologies such as 
satellite technology and satellite launch rocket. Each ASEAN member states also has different interests in the development of space technology, that's makes partial offers of cooperation from other countries to ASEAN member states (offers of bilateral or trilateral cooperation) thereby reducing the focus of ASEAN regional space cooperation. The different interests can make unclear cooperation funding mechanisms and the most important challenge is because of the economic gaps between ASEAN member states.

While the opportunities to strengthen ASEAN Space Technology Cooperation are based on the desire to realize the vision of the ASEAN Community. Furthermore, the existence of the Industrial Revolution 4.0 as a trigger for ASEAN member countries to develop their space technology. The space technology can finally be used to reach ASEAN SDGs. The development of space technology is also supported by the strategic position of the ASEAN region in the development of space technology (most ASEAN member states are in the Equatorial region), very suitable for the rocket technology, spacecraft, and satellite development.

Based on these opportunities and challenges, the main objects of space cooperation that can serve as guidelines in strengthening ASEAN Space Technology Cooperation, are cooperation in space technology, cooperation in space applications, cooperation in space environment utilization; and cooperation in space education. The 4 main objects of ASEAN Space Technology Cooperation will not only strengthen among ASEAN member states but also with regional and international space organizations and other countries that excel in space technology, which will support ASEAN space technology capabilities in facilitating and supporting the development and implementation of ASEAN space activities. ASEAN and its member states must work together to prepare and find the most appropriate and effective solutions to solve various problems that may arise with the strengthening of ASEAN Space Cooperation (Noichim, 2008). Making space as the focus of ASEAN cooperation is effective in supporting the achievement of SDGs in the Southeast Asia region and strengthening ASEAN's position as a more qualified regional association.

\section{References}

Abad, J. M. (1997). History the founding of ASEAN. Retrieved from https://asean.org/asean/aboutasean/history/.

Ali Mohd., A. M. (2011). Space activities in Malaysia. Institute of Space Science (ANGKASA), Universiti Kebangsaan Malaysia (UKM - National University of Malaysia). Retrieved from https://www.unoosa.org/documents/pd f/psa/activities/2011/hstiSeminar/HSTI.A lauddin.pdf.

Anwar, D. F. (1996). Regionalism versus globalism: A Southeast Asian perspective. Korean Journal of Defense Analysis, 8(2), 29-52.

ASEAN Secretariat. (2017a). ASEAN plan of action on science, technology and innovation (APASTI) 2016-2025. Retrieved from

https://asean.org/storage/2017/10/01APASTI-2016-2025-FINAL.pdf.

ASEAN Secretariat. (2017b). The ASEAN charter:

Retrieved from https://asean.org/wpcontent/uploads/images/archive/public ations/ASEAN-Charter.pdf.

Flanagan, K., et al. (2012). Internationalization of science: Dynamics and policies. Manchester: Institute of Innovation 
Research.

Fikkers, D. J., \& Horvat, M. (2014). Basic principles for effective international science, technology and innovation agreements: Main report. Luxembourg: Publications Office of the European Union. Retrieved from https://ec.europa.eu/research/iscp/pdf/ publications/Final Basic Principles

Science Tech Innovation-

MainReport.pdf.

Haro, R. M., \& Olascoaga, C. (2016). Space diplomacy: Useful initiatives for taking International cooperation beyond the skies. Presentation on UNISPACE+50 High Level Forum: Space as a Driver for Socio-Economic Sustainable Development, 20 - 24 November 2016 Dubai, United Arab Emirates, Mexican Space Agency. Retrieved from http://www.unoosa.org/documents/pdf /hlf/1st hlf Dubai/Presentations/74.p df.

Holsti, K. J. (1987). Politik internasional: Kerangka analisa. Jakarta: Pedoman Ilmu Jaya, 652-653.

Jani, K. (2016). Impact of international cooperation for sustaining space-science programs. Sam Nunn Security Program, Sam Nunn School of International Affairs Georgia Institute of Technology. Retrieved from https://arxiv.org/ftp/arxiv/papers/1610/1 610.08618.pdf.

LAPAN. (2019). Rencana strategis dan kerja LAPAN. Retrieved from https://www.lapan.go.id/page/rencanastrategis-dan-kerja.

Mahmud. (2011). Metode penelitian pendidikan. Bandung: CV Pustaka Setia, 100.

Mallik, A. (2016). Role of technology in international affairs. New Delhi: Pentagon Press, Institute for Defence Studies and Analyses. Retrieved from https://idsa.in/system/files/book/book role-of-technology-in-internationalaffairs a-mallik 1.pdf

Mubarak, F. (2018). Rethinking the digital divide: Emerging challenges in the new global economy. Finland: Turun Yliopiston Julkaisuja - Annales Universitatis Turkuensis. Retrieved from https://www.utupub.fi/bitstream/handl e/10024/145052/AnnalesE28Mubarak.pd f? sequence $=1$ \&isAllowed $=y$.

Mukherjee, A. (2018). International cooperation in space technology: An abstraction with fuzzy logic analysis. ISPRS Annals of the Photogrammetry, Remote Sensing and Spatial Information Sciences, Volume IV5, 2018 ISPRS TC V Mid-term Symposium "Geospatial Technology - Pixel to People”, 20-23 November 2018, Dehradun, India. Retrieved from https://www.isprs-ann-photogrammremote-sens-spatial-inf-sci.net/IV5/13/2018/isprs-annals-IV-5-13-2018.pdf.

Nazir, M. 2003. Metode penelitian. Jakarta: Ghalia.

Noichim, C. (2008). The ASEAN space organization legal aspects and feasibility. Retrieved from 
https://openaccess.leidenuniv.nl/bitstre am/handle/1887/13358/Full\%20text.pdf;s equence $=6$.

Noichim, C. (2010). ASEAN space organization in the beginning of ASEAN community era. Chiang-Rai. Thailand: Schooll of Law, Mae Fah Luang University.

Parks, T., Maramis, L, Sunchindah, A., \& Wongwatanakul, W. (2018). ASEAN as the architect for regional development cooperation: Advancing ASEAN centrality \& catalyzing action for sustainable development. San Fransisco: The Asia Fundations. Retrieved from https://asiafoundation.org/wpcontent/uploads/2018/09/ASEAN-asthe-Architect-for-Regional-DevelopmentCooperation.pdf.

Pusbindiklat LIPI. (2017). Modul Iandasan penelitian diklat jabatan fungsional peneliti tingkat pertama. Cibinong: Pusbindiklat Peneliti LIPI, 47.

Radzi, Z. M. (2015). International collaboration on space weather forecast. Space Weather Research \& Activities in Malaysia: From Research to Operational. Presented at the 3rd AOSWA Workshop, Fukuoka, Japan. Retrieved from http://aoswa.nict.go.jp/workshop_3/pr ogram/pdf/S1/S1-4.pdf.

Santos, S. C. (2008). Constructivism and regional integration theories: The application to mercosur. Paper presented at the Second WISC Conference. Slovenia: Faculty of Social Sciences, University of Ljubljana.
Sarma, N. (2019). Southeast Asian space programmes: Capabilities, challenges and collaborations. ORF Special Report No. 82, March 2019. New Delhi: Observer Research Foundation.

Schrogl, K. (2016). Space law \& diplomacy. Retrieved from http://www.iislweb.org/docs/2016keyno te.pdf.

Sese, R. M. (2015). Space research and development in the Philippines. Presented at the 22th APRSAF, Program Leader, National SPACE Development Program Focal Person, Philippine Space Science Education Program.

Subari, M. D., \& Azmi, H. (2016). Developing the space industry of Malaysia: The policy frameworks. JoSTIP Volume 2 Number 1 (June 2016). Malaysia: Perdana School of Science, Technology and Innovation Policy, UTM.

The Royal Society. (2010). New frontiers in science diplomacy: Navigating the changing balance of power. Retrieved from

https://www.aaas.org/sites/default/files

/New Frontiers.pdf.

Verbiest, J. A. (2011). Opportunities and challenges for the ASEAN economic community in a global perspective. Presentation on Workshop "Managing Regional and Global Governance in Asia”. Retrieved from https://www.bi.go.id/en/publikasi/lain/ artikel/Documents/ed2257dd82014071a 3cfbd331f9cde19131011__DrJPVerbiestOpp 
ortunitiesandchallenges.pdf.

Weiss, M. (2010). Malaysia-Indonesia Bilateral Relations: Sibling Rivals in a Fraught Family. In N. Ganesan \& Ramses Amer (Eds.). International relations in southeast asia: Between bilateralism and multilateralism. Singapore: Institute of Southeast Asian Studies, 171-198. 